\title{
KNOWLEDGE MANAGEMENT SYSTEM PADA BIRO ADMINISTRASI AKADEMIK AKADEMI PARIWISTA NUSANTARA
}

\author{
Yudi Akbar \\ Program Studi Informatika, Universitas Indraprasta PGRI \\ yudiakbar12@gmail.com
}

\begin{abstract}
Abstrak
Knowledge Management System (KMS) bertujuan untuk meningkatkan kualitas SDM dalam suatu organisasi dengan memperbaiki komunikasi antar karyawan dan meningkatkan penguasaan dengan melakukan transfer pengetahuan. Knowledge Management System (KMS) merupakan salah satu cara untuk menumbuhkan budaya saling berbagi knowledge (sharing knowledge) antar individu maupun organisasi. Pada penelitian ini, penulis mencoba mengembangkan model knowledge management system yang sesuai dengan kondisi yang ada pada Biro Administrasi Akademik Akademi Pariwisata Nusantara. Metodologi dalam penelitian ini menggunakan kerangka kerja model SSM, pembentukan knowledge menggunakan model SECI, Metode yang digunakan dalam merancang sistem adalah menggunakan Unified Modelling Language (UML) dan teknik pengujian fungsional sistem menggunakan metode FGD dengan tingkat keberhasilan $90 \%$ dan pengujian kualitas perangkat lunak menggunakan metode MCcall's dengan tingkat keberhasilan 87,75\%, hasil yang didapatkan dari penelitian ini adalah prototype Knowledge Management System yang dapat menyimpan pengetahuan dan pengalaman karyawan dengan baik sehingga menjadi sebuah solusi untuk berbagi sharing knowledge dan dapat mendukung kinerja karyawan di Biro Administrasi Akademik Pariwisata Nusantara.
\end{abstract}

Kata Kunci: Akademi Pariwisata Nusantara, Knowledge Managemet System, KMS, UML, FGD, MCcall's.

\begin{abstract}
Knowledge Management System (KMS) aims to improve the quality of human resources in an organization by improving communication among employees and to increase skill by transferring knowledge. Knowledge Management System (KMS) is one of many ways to foster a culture of knowledge sharing among individuals and organizations. In this research, the researcher tries to develop a model of knowledge management system suitable for existing condition at the Academic Administration Bureau of Nusantara Tourism Academy. The method used in this research is SSM model framework, while the knowledge is formed using SECI model. The system is designed by using Unified Modeling Language (UML) method. The functional system is tested using using FGD method with success rate of $90 \%$ and software quality is tested using MCcall's method with success rate of $87.75 \%$. The result of this research is the Knowledge Management System prototype that can be a solution to share knowledge because it can properly record the employees' knowledge and experience and can support the employees' performance at Academic Administration Bureau of Nusantara Tourism Academy.
\end{abstract}

Keywords: Nusantara Tourism Academy, Knowledge Managemet System, KMS, UML, FGD, MCcall's.

\section{PENDAHULUAN}

Pemanfaatan teknologi informasi saat ini telah merambah semua bidang kehidupan Teknologi Infprmasi telah mendorong munculnya cara cara baru untuk melakukan suatu pekerjaan. Dunia pendidikan dan dunia hiburan adalah dua bidang yang tergolong tinggi untuk pemanfaatan teknologi informasi. Teknologi informasi ini sangat penting jika dapat di manfaatkan sebanyakbanyaknya untuk dunia pendidikan. Banyak bentuk keberadaan dari pemanfaatan teknologi informasi dalam bidang pendidikan. Salah satunya adalah pemanfaatan knowledge management system. Konsep manajemen pengetahuan (knowladge management) adalah sebuah konsep baru di dunia bisnis yang telah di 
terapkan berbagai perusahaan besar di dunia pada prinsipnya. Konsep knowledge management bertujuan untuk meningkatkan kualitas SDM dalam suatu organisasi dengan memperbaiki komunikasi antara seluruh bagian organisasi dan meningkatkan penguasaan pengetahuan dengan melakukan transfer pengetahuan (knowledge sharing). Pengetahuan terbagi menjadi dua jenis, yaitu tacit knowledge dan expicit knowledge. Tacit knowledge adalah pengetahuan yang tersimpan dalam otak manusia, misalnya pemikiran, hafalan dan lain lain. Explicit knowledge adalah pengetahuan yang berada diluar kepala, misalnya buku, jurnal, dan lain-lain, konsep knowledge management berusaha untuk memadukan dan mengkombinasikan pengetahuan tersebut untuk meningkatkan daya saing. Dalam sebuah organisasi atau instansi, ketika seorang pegawainya meninggalkan instansi pengetahuanpun berlalu dengan mereka dan instansi tidak mengelola dengan baik, sehingga transfer pengetahuan tidak terjadi, akan sangat merepotkan saat terjadi perubahan organisasi misalnya perubahan SDM dan perubahan struktur organisasi. Akan menjadi masalah jika setiap orang hanya mengelola pengetahuan mereka sendiri. Sedangkan organisasi yang sukses mampu untuk secara konsisten menghasilkan pengetahuan baru atau inovasi discovery maupun invention, membagi dan menyebarkan kedalam organisasi, mengimplementasikan dalam teknologi atau produk. Organisasi perlu mengelola pengetauhan anggotanya untuk mengetahui kekuatan dan penempatan seluruh SDM, pengguna kembali pengetahuan yang sudah ada atau sudah di temukan, tidak perlu mengulang poroses kegagalan, mempercepat proses penciptaan pengetahuan baru dari pengetahuan yang ada, menjaga stabilitas pergerakan organisasi meskipun terjadi arus keluar masuk SDM. Konsep knowledge management dapat menjadi sebuah solusi untuk meningkatkan penguasaan pengetahuan dalam kegiatan administrasi akademik di suatu perguruan tinggi, peranan knowledge dalam suatu instansi merupakan suatu kebutuhan. Namun saat ini di Akademi Priwisata Nusantara masih banyak pengetahuan dan pengalaman yang belum di dokumentasi. , dan juga masih minim sekali budaya knowledge antara karyawan dengan karyawan dalam satu instansi kondisi ini diperparah dengan sering terjadinya pergantian karyawan perguruan tinggi dan karyawan baru perlu mengumpulkan knowledge kembali. Untuk itu sangat di butuhkan suatu system untuk mengelola pengetahuan di sebuah perguruan tinggi, suatu sistem yang mudah untuk digunakan kapan saja dan dimana saja serta menggunakan teknologi mutakhir. Hal inilah yang melatarbelakangi penulis untuk melakukan penelitian membuat knowledge Management System Biro Administrasi Akademik Akademi Pariwisata Nusantara Berbasis Web. Sejak lima tahun terakhir Akademi Pariwisata Nusantara mengalami arus keluar masuk karyawan dan pergantian karyawanpun terjadi, karyawan yang tercatat aktif berjumlah 22 orang dan itupun telah mengalami pergatian karyawan sebanyak 9 kali.

Masalah yang bias diidentifikasi adalah sebagai berikut :

1. Masih banyak pengetahuan dan pengalaman karyawan yang belum didokumentasikan sehingga ikut hilang pada saat karyawan tersebut keluar.

2. Terjadinya pergantian karyawan administrasi akademik setiap tahunnya mencapai dua kali pertahun, sehingga knowledge ikut berlalu dengan pergantian karyawan tersebut, karyawan baru perlu mengumpulkan knowledge kembali dan akan menghambat kinerja karyawan baru tersebut.

3. Tidak ada arus transfer knowledge antara karyawan yang sudah keluar dan 
karyawan baru sehingga pengetahuan yang ada sebelumnya ikut menghilang.

4. Belum ada Knowledge Management System (KMS) yang dapat diakses melalui web pada Akademi Pariwisata Nusantara.

Knowledge management system merupakan pekerjaan yang lingkupnya luas dan memakan waktu yang lama, oleh karena itu penelitian ini tidak akan membuat suatu system lengkap seluruh Akademi Pariwisata Nusantara, agar penelitian ini focus dan terarah maka penelitian ini di batasi menjadi :

1. Menganalisa tentang knowledge dalam kegiatan administrasi akademik akademi pariwisata nusantara.

2. Menganalisa kebutuhan system dalam kegiatan administrasi akademik akademi pariwisata nusantara.

3. Membuat prototipe KMS dalam bentuk aplikasi web.

\section{A.TujuanPenelitian}

Berdasarkan Pendahulian di atas maka tujuan penelitian ini adalah :

1.Memberikan solusi yang efektif dan efisien melalui KMS pada karyawan administrasi akademik dalam rangka membantu meningkatkan kinerja saat menjalankan pekerjaannya.

2. Membuat KMS pada biro Administrasi Akademik Akademi Pariwisata Nusan Tara.

\section{B. Manfaat Penelitian}

Penelitian ini diharapkan dapat memberikan sumbangan dalam memperkaya penerapan knowledge management dalam suatu organisasi. Selain itu penelitian ini diharapkan dapat menjadi bahan referensi bagi penelitian berikutnya.

\section{Teori}

Dalam bahasa sehari - hari, dalam bidang tertentu, dan dalam beberapa displin ilmu, kata knowledge (pengetahuan) sering diartikan dalam berbagai makna atau pengertian. Sebelum berbicara mengenai manajemen pengetahuan seseorang harus mengetahui atau mendefinisikan arti dari knowledge (pengetahuan). Hal ini penting untuk di pahami, karena bagian tersulit dalam mendefinisikan pengetahuan muncul dari hubungan antara dua konsep, yaitu data dan informasi [3] Untuk memudahakan pemahaman dalam strukturisasi data, informasi dan knowledge, perlu diketahui perbedaan diantara ketiganya. Data adalah fakta yang menyampaikan sesuatu yang spesifik dan tidak sedang digunakan pada proses keputusan, biasanya tidak memberikan informasi lebih lanjut [3].

Informasi merupakan suatu hasil dari pemrosesan dat a menjadi sesuatu yang bermakna bagi yang menerimanya, sebagaimana dikemukakan oleh Vercellis "Information is the outcome of extraction and processing activities carried out on data, and it appears meaningful for those who receive it in a specific domain." [6].

Knowledge adalah informasi yang digunakan untuk membuat keputusan dan tindakan yang sesuai, ditingkatkan oleh pengalaman dan kompetensi baik individu atau kelompok dalam suatu organisasi [6].

Untuk memahami perbedaan antara data, informasi dan pengetahuan, harus dapat digaris bawahi nilai hirarkinya. Berdasarkan Hirarki, pengetahuan, (Knowledge) ada pada tingkat tertinggi dalam hirarki dengan informasi di tingkat menengah dan data di tingkat terendah [1].

Dikalangan bisnis, Knowledge Management (KM) menjadi salah satu topik pembicaraan yang hangat. Ini karena hal yang dilakukan pengelola bisnis pada setiap harinya harus berhadapan pada sederet data dan informasi, baik yang bersifat kualitatif maupun kuantitatif. Ada banyak definisi yang dikemukakan oleh para ahli 
mengenai Knowledge Management, seperti yang dikemukakan oleh Karl-Erik Sveiby, professor KM di Hanken School of Economics di Helsinki, Finlandia, menyebutnya, "menciptakan nilai tambah dengan memanfaatkan assetaset intangible." [2].

Manajemen adalah kegiatan-kegiatan yang direncanakan, diimplementasikan, dan dikendalikan oleh suatu organisasi dengan menetapkan sasaran-sasaran untuk kerja yang dapat disempurnakan sesuai kondisi lingkungan yang berubah-ubah [4].

Banyak definisi yang dibuat oleh berbagai pakar untuk menjelaskan pengertian sistem. Pada umumnya definisi sistem mengandung dua konotasi yaitu benda atau entitas dan proses atau metode. Schrode dan Voich dalam bukunya yang berjudul Organization and Manajement: Basic System Concept, menyatakan bahwa sistem adalah "whole compounded of several parts" (suatu kesatuan yang tersusun dari sejumlah elemen) [5].

\section{METODOLOGI PENELITIAN}

Penelitian ini menggunakan metode penelitian Deskriptif Kualitatif dengan metode studi kasus yang bertujuan untuk mendapatkan gambaran yang lebih mendalam dan lengkap dari obyek yang akan diteliti. Kerangka kerja yang akan digunakan dalam penelitian ini adalah kerangka kerja model SSM, perancangan system dengan UML.

\section{A. Metode pemilihan Sampling}

Metode pengambilan sample dalam penelitian ini adalah purposive sampling. Pengambilan sampel dengan purposive sampling merupakan teknik pengambilan sampel dengan mengambil Peserta FGD yang terpilih betul oleh peneliti menurut ciri-ciri spesifik yang dimilki oleh sampel tersebut Adapun criteria pemilihan peserta FGD sebagai sampel penelitian ini adalah:

1. Karyawan yang memiliki masa kerja lebih dari 1 tahun.

2. Dapat menggunakan aplikasi berbasis Web.

\section{B. Metode Pengumpulan Data}

Pengumpulan data dilakukan untuk memperoleh informasi yang dibutuhkan dalam rangka mencapai tujuan penelitian. Tujuan yang diungkapkan dalam bentuk hipotesismerupakan jawaban sementara terhdap pertanyaan penelitian. Metode pengumpulan data bisa dilakukan dengan cara:

1. Wawancara

Wawancara dilakukan dengan wawancara terstruktur. Dalam wawancara tersebut peneliti menyiapkan daftar pertanyaan yang berkaitan dengan pengembangan

Knowledge Management System Administrasi Akademi pariwisata Nusantara. Pertanyaan-pertanyaan untuk mendapatkan data yang berkaitan dengan Knowledge Management yang sedang berjalan saat ini, kebutuhan fungsional, non-fungsional, dan pengguna untuk Knowledge Management System yang akan dikembangkan.

2. Observasi

Pada kegiatan observasi ini dilakukan dengan mengumpulkan data melalui pengamatan langsung terhadap fenomenafenomena yang terjadi di lokasi penelitian.

3. Studi Pustaka

Pada metode pengumpulan data ini diperoleh dengan mempelajari, meneliti dan membaca buku, jurnal dan tesis yang Berhubungan dengan Knowledge Management System.

\section{Instrumentasi}

Dalam penelitian ini instrument yang digunakan dalam pengumpulan data, antara lain :

1. Wawancara, daftar pertanyaan wawancara, instrument ini digunakan dalam pengunpulan data dengan wawancara. 
2. Observasi, instrument yang digunakan adalah penelitian yang melakukan pengamatan objek penelitian.

3. Studi Pustaka, instrument ini digunakan dalam pengumpulan data dengan studi pustaka.

\section{Teknik Analisis Data}

Teknik analisis data merupakan cara menganalisis data penelitian untuk menjawab permasalahan yang tampak dan menguji hipotesa.eknik analisis data dalam penelitian ini menggunakan SSM, SSM dibagi menjadi dua tahapan utama. Pertama, tahap realitas dengan lima langkah. Langkah-langkah pada tahap realitas tersebut, yaitu :

1. Studi pengenalan masalah studi pengenalan masalah melalui proses interview kepada partisipan.

2. Ekspresi masalah

Menyusun atau memetakan situasi suatu masalah (Strukturisasi masalah).

3. Membandingkan model realitas.

Membandingkan model konseptual dengan masalah yang telah terstruktur.

4. Mengembangkan intervensi tahap intervensi didapatkan gambaran yang jelas tentang situasi kompleks yang melibatkan berbagai faktor yang harus diperbaiki dalam proses penciptaan knowledge.

5. Mengusulkan KMS

Pada tahap terakhir SSM diajukan sebuah usulan desain arsitektur KMS yang dibangun dari hasil indepth interview, konfirmasi, focus group, dan tinjauan pustaka.

Tahap ke dua adalah systems thinking dengan dua langkah yaitu :

1. Makna Nilai

Menyusun definisi permasalahan yang di formulasikan dari hasil struktirisasi masalah.

2. Mengembangkan model konsepsual.

Membuat model konsepsual atas dasar hasil definisi permasalahan.
Teknik analisis data adalah tahapan awal berdasarkan data-data yang telah dikumpulkan melalui tahapan wawancara, observasi dan studi pustaka untuk mendapatkan kebutuhan-kebutuhan sistem yang akan digunakan dalam pemecahan masalah yang tepat. Sumber data yang telah dikumpulkan kemudian diolah secara rinci dan dikembangkan dengan bantuan metode-metode yang telah dipilih oleh peneliti guna membantu perancangan sistem yang diinginkan.Teknik analisis data yang digunakan adalah analisis deskriptif kuantitatif.

\section{HASIL PEMBAHASAN}

\section{A. Karakteristik Responden}

Responden yang dipilih dalam proses FGD nantinya memiliki kriteria dari berbagai divisi dan berbagai jabatan. Responden ini nantinya akan memvalidasi apakah solusi dari komponen KM yang dibuat sesuai dengan yang diinginkan karyawan dalam akademi pariwisata Nusantara dan responden ini dapat memberikan masukan atau tambahan solusi dari solusi yang sudah diajukan. Berikut karakteristik dari responden FGD dalam memvalidasi solusi yang telah di buat:

Tabel 1. Karakteristik Responden FGD Untuk Solusi Komponen KM

\begin{tabular}{|c|c|c|c|c|}
\hline Kode & Nama & $\begin{array}{l}\text { Jabata } \\
n\end{array}$ & $\begin{array}{l}\text { Lama } \\
\text { kerja }\end{array}$ & $\begin{array}{l}\text { Pendi } \\
\text { dikan }\end{array}$ \\
\hline $\mathrm{AH}$ & $\begin{array}{l}\text { Amir } \\
\text { Hamzah }\end{array}$ & $\begin{array}{l}\text { Staff } \\
\text { SDM }\end{array}$ & $\begin{array}{c}8 \\
\text { tahun }\end{array}$ & $\mathrm{S} 2$ \\
\hline RD & Ramdani & $\begin{array}{l}\text { Staff } \\
\text { Penja } \\
\text { min } \\
\text { Mutu }\end{array}$ & $\begin{array}{l}6 \\
\text { Tahu } \\
n\end{array}$ & $\mathrm{~S} 2$ \\
\hline AJ & Ajat & $\begin{array}{l}\text { Staff } \\
\text { Akade } \\
\text { mik }\end{array}$ & $\begin{array}{l} \\
\text { Tahu } \\
\mathrm{n}\end{array}$ & S1 \\
\hline FR & $\begin{array}{l}\text { Farmen } \\
\text { Rizal }\end{array}$ & $\begin{array}{l}\text { Direkt } \\
\text { ur } \\
\text { Akpar }\end{array}$ & $\begin{array}{l}11 \\
\text { tahun }\end{array}$ & $\mathrm{S} 2$ \\
\hline AM & $\begin{array}{l}\text { Ahmad } \\
\text { Mulyana }\end{array}$ & $\begin{array}{l}\text { Wakil } \\
\text { Direkt } \\
\text { ur }\end{array}$ & $\begin{array}{l}8 \\
\text { tahun }\end{array}$ & $\mathrm{S} 2$ \\
\hline
\end{tabular}




\section{B. Hasil Validasi Solusi Analisis Komponen KM}

Berdasarkan Focus Group Discussion (FGD) yang dilakukan penulis terhadap responden, selanjutnya dapat direkapitulasi hasil pengujian dari responden dalam FGD. Hasil dari FGD ini nantinya akan dipetakan ke dalam proses konversi knowledge menggunakan model SECI Nonaka. Berikut hasil dari validasi solusi analisis komponen knowledge management menggunakan FGD.

Tabel 2. Hasil Validasi solusi KM

\begin{tabular}{|c|c|c|c|c|}
\hline \multirow{2}{*}{$\begin{array}{l}\mathrm{N} \\
\mathrm{O}\end{array}$} & \multirow{2}{*}{$\begin{array}{l}\text { Solusi } \\
\text { Responden }\end{array}$} & \multicolumn{2}{|c|}{$\begin{array}{l}\text { Jawaban } \\
\text { Responden }\end{array}$} & \multirow{2}{*}{$\begin{array}{c}\text { Kesimp } \\
\text { ulan }\end{array}$} \\
\hline & & $\begin{array}{l}\text { Diterim } \\
\text { a }\end{array}$ & $\begin{array}{l}\text { Ditola } \\
\mathrm{k}\end{array}$ & \\
\hline 1 & $\begin{array}{l}\text { Membuat } \\
\text { panduan dalam } \\
\text { mengerjakanse } \\
\text { suatu } \\
\text { pekerjaan } \\
\text { sehingga } \\
\text { karyawan baru } \\
\text { dapat lebih } \\
\text { cepat } \\
\text { beradaptasi. }\end{array}$ & 5 & & Diterima \\
\hline 2 & $\begin{array}{l}\text { Memberikan } \\
\text { training dasar } \\
\text { atau workshop } \\
\text { yang } \\
\text { bertujuan } \\
\text { untuk } \\
\text { menambah } \\
\text { wawasan } \\
\text { karyawan } \\
\text { dalam } \\
\text { enyelesaikan } \\
\text { pekerjaan atau } \\
\text { masalah } \\
\text { mereka. }\end{array}$ & 5 & & Diterima \\
\hline \multirow[t]{2}{*}{3} & $\begin{array}{l}\text { Melakukan } \\
\text { pembagian job } \\
\text { description }\end{array}$ & & & \\
\hline & $\begin{array}{l}\text { yang jelas } \\
\text { kepada } \\
\text { seluruh } \\
\text { karyawan } \\
\text { sesuai dengan } \\
\text { kapasitas } \\
\text { karyawankebut } \\
\text { uhan }\end{array}$ & 5 & & Diterima \\
\hline 4 & $\begin{array}{l}\text { Membuat } \\
\text { untuk divisi } \\
\text { yang belum } \\
\text { memiliki SOP }\end{array}$ & 5 & & \\
\hline
\end{tabular}

\begin{tabular}{|c|c|c|c|}
\hline & $\begin{array}{l}\text { dan karyawan } \\
\text { perlu disiplin } \\
\text { dalam } \\
\text { menerapkan } \\
\text { SOP. }\end{array}$ & & \\
\hline 5 & $\begin{array}{l}\text { Membuat } \\
\text { jadwal diskusi } \\
\text { untuk } \\
\text { menyelesaikan } \\
\text { masalah atau } \\
\text { sekedar } \\
\text { sharing } \\
\text { pengetahuan } \\
\text { atau } \\
\text { pengalaman }\end{array}$ & 5 & Diterima \\
\hline 6 & $\begin{array}{l}\text { Menyediakan } \\
\text { fasilitas } \\
\text { submit artikel, } \\
\text { menyimpan } \\
\text { file dalam } \\
\text { suatu sistem. }\end{array}$ & 5 & Diterima \\
\hline
\end{tabular}

Melihat hasil yang didapatkan oleh FGD baik dari tanggapan, kesimpulan dari responden, berikut adalah solusi solusi yang diterima:

Tabel 3. Solusi Komponen KM yang sudah tervalidasi

\begin{tabular}{cl}
\hline No & Solusi Komponen KM yang sudahTervalidasi \\
\hline 1 & $\begin{array}{l}\text { Membuat panduan dalam mengerjakan sesuatu } \\
\text { pekerjaan sehingga } \\
\text { karyawan baru dapat lebih cepat beradaptasi. }\end{array}$ \\
\hline 2 & $\begin{array}{l}\text { Memberikan training dasar atau workshop yang } \\
\text { bertujuan untuk menambah } \\
\text { wawasan karyawan dalam menyelesaikan } \\
\text { pekerjaan atau masalah mereka. }\end{array}$ \\
\hline 3 & $\begin{array}{l}\text { Melakukan pembagian job description yang jelas } \\
\text { kepada seluruh karyawan sesuai dengan kapasitas } \\
\text { karyawan. }\end{array}$ \\
\hline 4 & $\begin{array}{l}\text { Membuat SOP untuk divisi yang belum memiliki } \\
\text { SOP dan karyawan perlu disiplin dalam } \\
\text { menerapkan SOP. }\end{array}$ \\
\hline 5 & $\begin{array}{l}\text { Membuat jadwal diskusi untuk menyelesaikan } \\
\text { masalah atau sekedar sharing pengetahuan atau } \\
\text { pengalaman. }\end{array}$ \\
\hline 6 & $\begin{array}{l}\text { Menyediakan fasilitas submit artikel, } \\
\text { menyimpan file dalam knowledge management } \\
\text { system. }\end{array}$ \\
\hline
\end{tabular}

Dari rangkaian analisis di atas untuk menentukan proses Knowledge Management System maka dapat dibuat model knowledge management system sebagai berikut : 


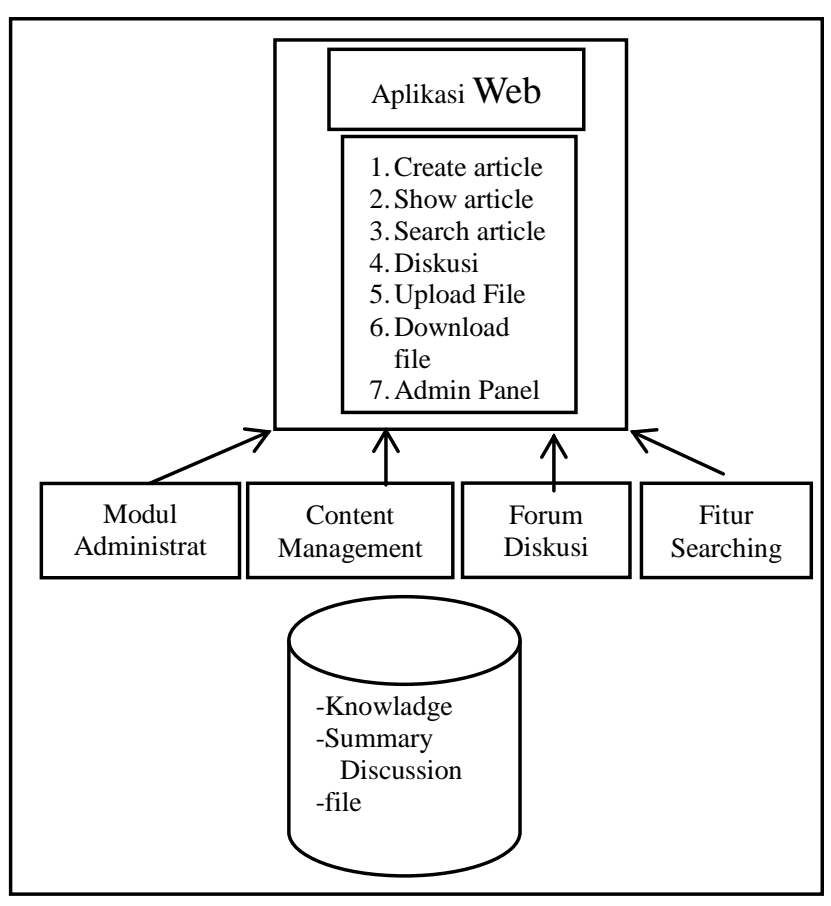

Gambar 1 Arsitektur KMS

\section{Tampilan Prototipe Knowledge Management System}

Knowledge management system untuk Akademi ariwisata Nusantara apabila admin ingin login, maka pertama kali yang akan muncul adalah halaman awal yang mengharuskan karyawan Akademi Pariwisata Nusantara untuk login terlebih dahulu. Hal ini untuk menjaga agar sistem ini hanya bisa diakses oleh orang-orang yang berhak saja, yaitu administrator dan user biasa. Administrator adalah orang yang mengelola user yang ada di knowledge management system ini.

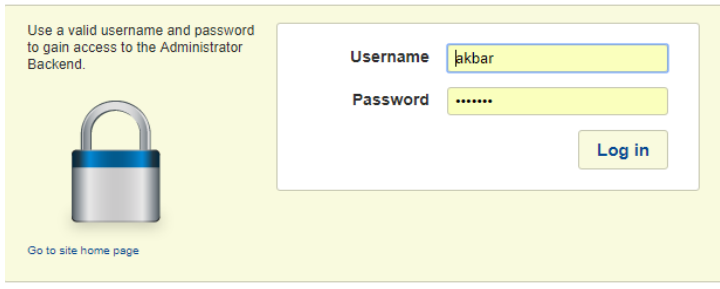

Gambar 2. Halama Login Administrator Knowledge Management System

Administrator akan masuk pada control panel dan mengakses control panel untuk mengelola pesan-pesannya, dan knowaldge yang ada, Di dalam menu ini, admin dapat melakukan management user pesan, menerima pesan dan membuat pesan, berikut tampilan dari control panel.

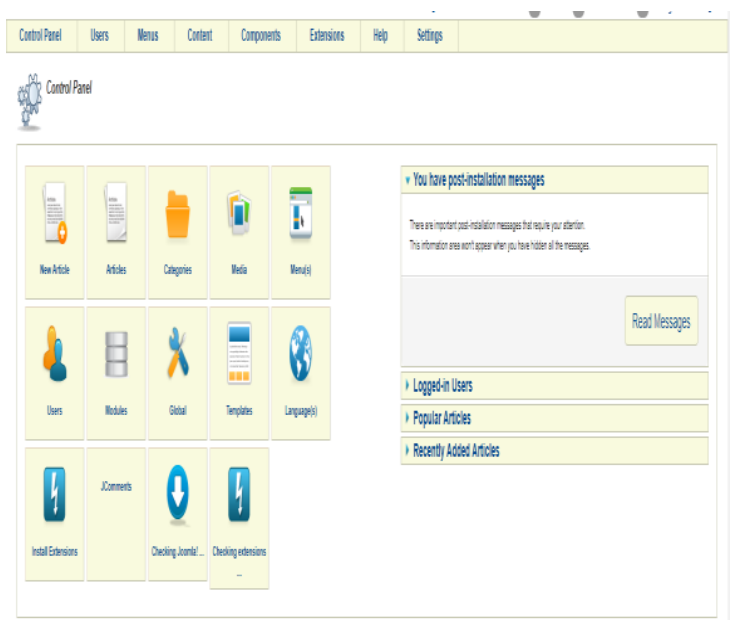

\section{Gambar 3. Halaman Control Panel}

Untuk membuat diskusi, user dapat memilih menu New topic, kemudian melengkapi data pengirim, subject dan isi halaman menu diskusi dapat dilihat pada gambar 4 berikut ini :

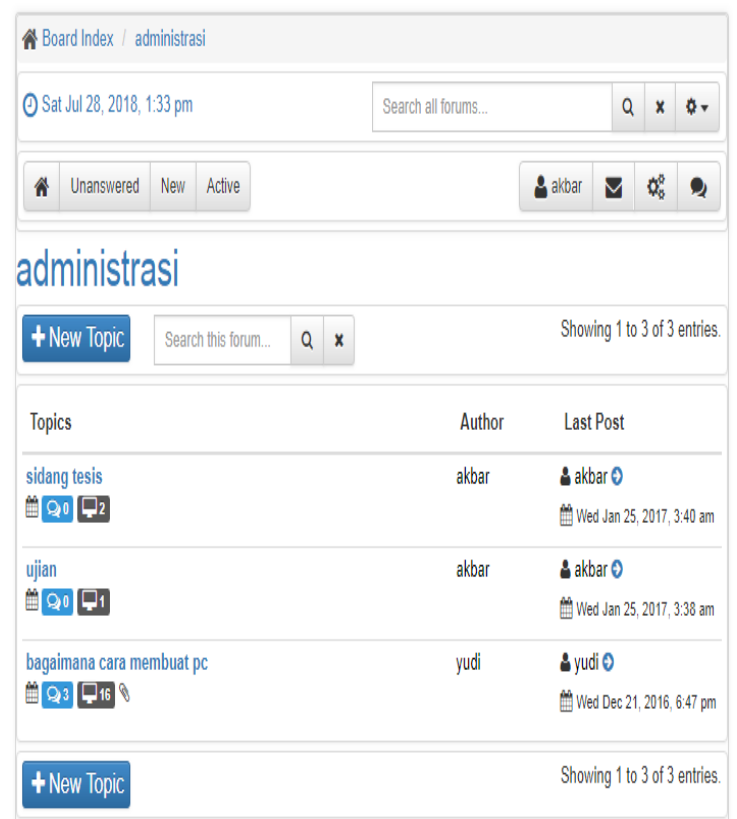

Gambar 4. Halaman Diskusi

untuk membuat pesan baru, user dapat memilih menu New Message, kemudian melengkapi data pengirim, subject dan isi pesannya. Menu New Message dapat dilihat pada gambar 5 berikut ini : 


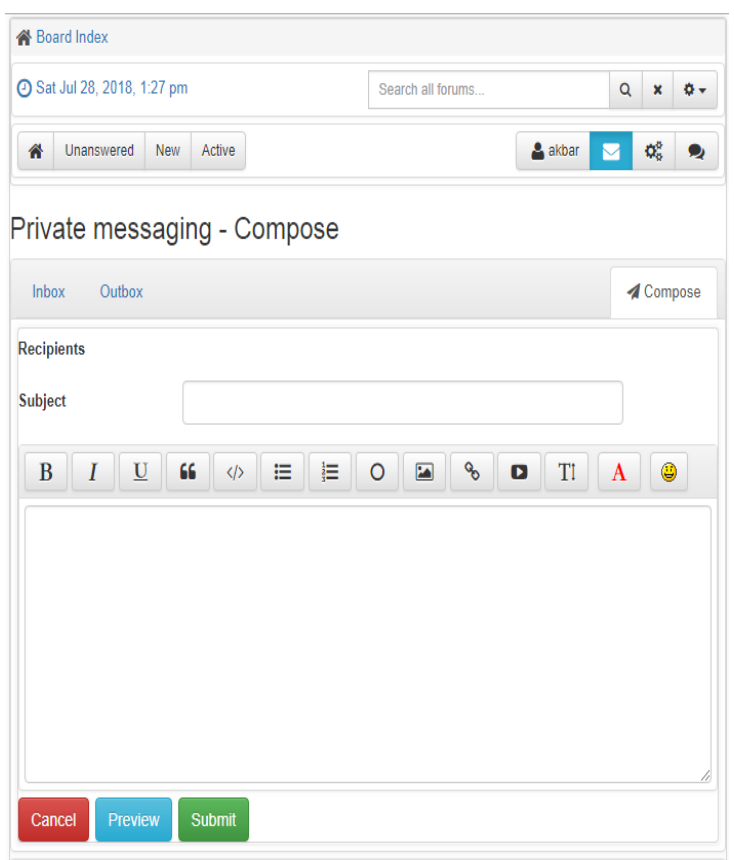

Gambar 5. Halaman Pesan

\section{Hasil Pengujian Spesifikasi Fungsional}

Berdasarkan Focus Group Discussion, selanjutnya dapat direkapitulasi hasil pengujian dari Peserta FGD.

\begin{tabular}{|c|c|c|c|c|}
\hline \multirow{2}{*}{ No } & \multirow{2}{*}{$\begin{array}{l}\text { Kebutuhan } \\
\text { Fungsi }\end{array}$} & \multicolumn{2}{|c|}{$\begin{array}{l}\text { Jawaban Peserta } \\
\text { FGD }\end{array}$} & \multirow{2}{*}{$\underset{\mathrm{n}}{\text { Kesimpula }}$} \\
\hline & & $\begin{array}{c}\text { Diterim } \\
\mathrm{a}\end{array}$ & $\begin{array}{c}\text { Ditola } \\
\mathrm{k}\end{array}$ & \\
\hline 1 & $\begin{array}{l}\text { Menampilkan } \\
\text { halaman login } \\
\text { untuk user }\end{array}$ & 5 & & Diterima \\
\hline 2 & $\begin{array}{l}\text { Dapat } \\
\text { menampilkan } \\
\text { menu profil } \\
\text { user }\end{array}$ & 5 & & Diterima \\
\hline 3 & $\begin{array}{l}\text { Dapat } \\
\text { Menampilkan } \\
\text { kategori } \\
\text { knowledge }\end{array}$ & 5 & & Diterima \\
\hline 4 & $\begin{array}{l}\text { Dapat } \\
\text { menampilkan } \\
\text { knowledge }\end{array}$ & 5 & & Diterima \\
\hline 5 & $\begin{array}{l}\text { Dapat } \\
\text { menginput } \\
\text { knowledge } \\
\text { baru }\end{array}$ & 5 & & Diterima \\
\hline 6 & $\begin{array}{l}\text { Dapat } \\
\text { mengedit } \\
\text { knowledge }\end{array}$ & 3 & 2 & Diterima \\
\hline
\end{tabular}

\begin{tabular}{|c|c|c|c|c|}
\hline 7 & $\begin{array}{l}\text { Dapat } \\
\text { menghapus } \\
\text { knowledge }\end{array}$ & 3 & 3 & Diterima \\
\hline 8 & $\begin{array}{l}\text { Dapat } \\
\text { memeberikan } \\
\text { komentar } \\
\text { pada artikel }\end{array}$ & 5 & & Diterima \\
\hline 9 & $\begin{array}{l}\text { Dapat } \\
\text { mengupload } \\
\text { file }\end{array}$ & 5 & & Diterima \\
\hline $\begin{array}{l}1 \\
0\end{array}$ & $\begin{array}{l}\text { Dapat } \\
\text { melakukan } \\
\text { diskusi suatu } \\
\text { topik forum }\end{array}$ & 5 & & Diterima \\
\hline 11 & $\begin{array}{l}\text { Dapat } \\
\text { melakukan } \\
\text { pencarian }\end{array}$ & 5 & & Diterima \\
\hline $\begin{array}{l}1 \\
2\end{array}$ & $\begin{array}{l}\text { Hanya } \\
\text { membutuhka } \\
\text { n kurang } 2 \\
\text { menit untuk } \\
\text { login aplikasi. }\end{array}$ & 4 & 1 & Diterima \\
\hline
\end{tabular}

Berdasarkan hasil tersebut di atas, secara keseluruhan responden menyatakan bahwa knowledge management system berbasis Web ini dapat di terima fungsinya dan menyetujui hasil dari pengujian yang dilakukan.

\section{E. Hasil Pengujian Validasi Fungsi Keseluruhan Sistem}

Tanggapan untuk fungsi aplikasi KMS yang dapat menyediakan pengelolaan knowledge yang reintegrasi secara baik dan sistematis serta dapat meningkatkan kecepatan pencarian, penyebaran, penyerapan dan pengembangan knowledge.

1. Tanggapan : Aplikasi KMS ini dapat berfungsi menyediakan pengelolaan knowledge yang terintegrasi secara baik dan sistematis. 
Tabel 5. Tanggapan fungsi aplikasi dapat menyediakan pengelolaan knowledge yang reintegrasi dan sistematis

\begin{tabular}{|c|c|c|c|}
\hline No & Kode & Tanggapan & Kesimpulan \\
\hline 1 & FR & $\begin{array}{lr}\text { Saya } & \text { sudah } \\
\text { mencoba } & \text { dan } \\
\text { aplikasi } & \text { ini } \\
\text { berjalan } & \\
\text { dengan baik } \\
\text { dalam } \\
\text { mengelola } \\
\text { knowledge }\end{array}$ & Diterima \\
\hline 2 & AM & $\begin{array}{l}\text { Menurut saya } \\
\text { aplkasi ini } \\
\text { sudah berjalan } \\
\text { dengan baik } \\
\text { dan dapat } \\
\text { mengelola } \\
\text { knowledge } \\
\text { dengan baik }\end{array}$ & Diterima \\
\hline 3 & $\mathrm{AH}$ & $\begin{array}{l}\text { Dengan } \\
\text { adanya } \\
\text { aplikasi kms } \\
\text { Biro } \\
\text { administrasi } \\
\text { akademik } \\
\text { tidak rumit } \\
\text { dalam } \\
\text { menyelesaikan } \\
\text { pekerjaan }\end{array}$ & Diterima \\
\hline 4 & RD & $\begin{array}{lr}\text { Saya rasa } \\
\text { aplikasi sudah } \\
\text { berjalan } \\
\text { dengan baik } \\
\text { dan mengelola } \\
\text { knowledge } \\
\text { dengan baik }\end{array}$ & Diterima \\
\hline 5 & $\mathrm{AJ}$ & $\begin{array}{l}\text { Semua fungsi } \\
\text { berjalan } \\
\text { dengan baik } \\
\text { dan } \\
\text { pengolahan } \\
\text { knowledgenya } \\
\text { dapat } \\
\text { diterapkan } \\
\text { dengan baik }\end{array}$ & Diterima \\
\hline
\end{tabular}

Berdasarkan tabel mengenai jawaban responden hasil FGD diatas dapat dilihat bahwa tangapan responden menyetujui fungsi aplikasi KMS dapat berfungsi menyediakan knowledge terintegrasi.

\section{Tabel 6.Tanggapan fungsi aplikasi dapat meningkatkan kecepatan pencarian, penyebaran, penyerapan dan pengembangan knowledge}

\begin{tabular}{|c|c|c|c|}
\hline $\mathrm{No}$ & Kode & Tanggapan & Kesimpulan \\
\hline 1 & FR & $\begin{array}{l}\text { Aplikasi ini } \\
\text { dapat membantu } \\
\text { karyawan yang } \\
\text { sedang } \\
\text { mendapat } \\
\text { masalah dalam } \\
\text { pekerjaan }\end{array}$ & Diterima \\
\hline 2 & $\mathrm{AH}$ & $\begin{array}{l}\text { Sangat setuju } \\
\text { dan membantu }\end{array}$ & Diterima \\
\hline 3 & $\mathrm{RD}$ & $\begin{array}{l}\text { Kecepatan dari } \\
\text { aplikasi sudah } \\
\text { dapat } \\
\text { menyebarkan } \\
\text { dan } \\
\text { mengembangkan } \\
\text { knowledge } \\
\text { dengan baik }\end{array}$ & Diterima \\
\hline 4 & $\mathrm{AM}$ & $\begin{array}{l}\text { Menurut saya } \\
\text { aplikasi ini dapat } \\
\text { meningkatkan } \\
\text { kecepatan } \\
\text { pencarian } \\
\text { knowledge bagi } \\
\text { karyawan yang } \\
\text { mendapat } \\
\text { masalah }\end{array}$ & Diterima \\
\hline 5 & $\mathrm{AJ}$ & $\begin{array}{l}\text { Media diskusi } \\
\text { yang ada di } \\
\text { aplikasi ini dapat } \\
\text { dengan cepat } \\
\text { menyebarkan } \\
\text { informasi } \\
\text { maupun } \\
\text { knowledge }\end{array}$ & Diterima \\
\hline
\end{tabular}

Berdasarkan tabel mengenai jawaban responden hasil FGD diatas dapat dilihat bahwa tangapan responden menyetujui fungsi aplikasi KMS dapat berfungsi meningkatkan kecepatan pencarian, penyebaran, dan pengembangan knowledge.

\section{F. Pengujian Kualitas}

Tanggapan Responden terhadap tingkat kualitas aplikasi KMS ini berdasarkan jawaban indikator kualitas software menurut McCall's, terdiri dari beberapa tahap sebagai berikut:

1. Menggunakan kriteria yang digunakan 
untuk menggunakan suatu faktor.

2. Menggunakan bobot (w) dari setiap kriteria $(0,=\mathrm{w},=1)$.

3. Menentukan skala nilai kriteria, dimana skala penilaian yang digunakan antara 1-5, dimana 1 adalah penilaian minimum dari 5 penilaian maksimum.

4. Memasukkan nilai pada tiap kriteria hasil dari penilaian responden.

5.Menghitung nilai total dengan rumus $\mathrm{Fa}=\mathrm{w} 1 \mathrm{c} 1+\mathrm{w} 2 \mathrm{c} 2+\ldots+$ wncn. $\mathrm{Fa}$ adalah nilai total dari faktor a, wn adalah bobot untuk kriteria $\mathrm{n}$, dan $\mathrm{cn}$ adalah nilai untuk kriteria n.

\section{Tabel 7. Kriteria Persentase Tanggapan Responden Terhadap Skor Ideal}

\begin{tabular}{cc}
\hline $\begin{array}{c}\% \\
\text { Jumlah } \\
\text { Skor }\end{array}$ & Kriteria \\
\hline $20,00 \%-$ & Tidak Baik \\
$36,00 \%$ & \\
\hline $36,01 \%-$ & Kurang Baik \\
$52,00 \%$ & \\
\hline $52,01 \%-$ & Cukup \\
$68,00 \%$ & \\
\hline $68,01 \%-$ & Baik \\
$84,00 \%$ & \\
\hline $84,01 \%-$ & Sangat Baik \\
$100 \%$ & \\
\hline
\end{tabular}

Perhitungan masing-masing faktor kualitas yang dilakukan berdasarkan kriteria yang telah ditentukan adalah sebagai berikut:

Tabel 8. Pengujian Kualitas Faktor

\begin{tabular}{|c|c|c|c|c|c|c|c|c|c|}
\hline \multicolumn{10}{|c|}{ Efficiency } \\
\hline \multirow[t]{2}{*}{ Faktor } & \multirow[t]{2}{*}{ Kriteria } & \multicolumn{5}{|c|}{$\begin{array}{l}\text { Tanggapan } \\
\text { Responden }\end{array}$} & \multirow[t]{2}{*}{$\begin{array}{l}\text { Aver } \\
\text { age }\end{array}$} & \multirow[t]{2}{*}{$\begin{array}{l}\text { Bo } \\
\text { bot }\end{array}$} & \multirow[t]{2}{*}{$\begin{array}{l}\mathrm{Ni} \\
\text { lai }\end{array}$} \\
\hline & & 1 & 2 & 3 & 4 & 5 & & & \\
\hline \multirow[t]{3}{*}{$\begin{array}{l}\text { Effici } \\
\text { ency }\end{array}$} & $\begin{array}{c}\text { Compet } \\
\text { eness }\end{array}$ & 4 & 5 & 4 & 4 & 4 & 4,2 & 0,4 & $\begin{array}{c}1,7 \\
6\end{array}$ \\
\hline & $\begin{array}{l}\text { Consist } \\
\text { ency }\end{array}$ & 5 & 4 & 4 & 5 & 5 & 4,8 & 0,3 & $\begin{array}{c}1,3 \\
8\end{array}$ \\
\hline & $\begin{array}{l}\text { Tracebil } \\
\text { ity }\end{array}$ & 4 & 5 & 5 & 4 & 4 & 4,4 & 0,3 & $\begin{array}{c}1,3 \\
2\end{array}$ \\
\hline
\end{tabular}

$$
\begin{aligned}
\text { Efficiency }= & \mathrm{w} 1 \mathrm{n} 1^{\prime}+\mathrm{w} 2 \mathrm{n} 2{ }^{\prime}+\mathrm{w} 3 \mathrm{n} 3 \\
= & 1.76+1.38+1.32 \\
& 4.46 * 20 / 100 * 100 \% \\
= & 89,2 \% \text { (Sangat Baik) }
\end{aligned}
$$

\begin{tabular}{|c|c|c|c|c|c|c|c|c|c|}
\hline \multirow[t]{2}{*}{ Faktor } & \multirow[t]{2}{*}{ Kriteria } & \multicolumn{5}{|c|}{$\begin{array}{l}\text { Tanggapan } \\
\text { Responden }\end{array}$} & \multirow[t]{2}{*}{$\begin{array}{l}\text { Aver } \\
\text { age }\end{array}$} & \multirow[t]{2}{*}{$\begin{array}{l}\text { Bo } \\
\text { bot }\end{array}$} & \multirow[t]{2}{*}{$\begin{array}{l}\mathrm{Ni} \\
\text { lai }\end{array}$} \\
\hline & & 1 & 2 & 3 & 4 & 5 & & & \\
\hline \multirow[t]{4}{*}{$\begin{array}{c}\text { Reliab } \\
\text { ility }\end{array}$} & $\begin{array}{l}\text { Accura } \\
\text { cy }\end{array}$ & 3 & 4 & 5 & 4 & 4 & 4 & 0,3 & 1,2 \\
\hline & $\begin{array}{l}\text { Consist } \\
\text { ency }\end{array}$ & 4 & 5 & 4 & 5 & 5 & 4,6 & 0,2 & $\begin{array}{c}0,8 \\
5\end{array}$ \\
\hline & $\begin{array}{l}\text { Error } \\
\text { Toleran } \\
\text { ce } \\
\end{array}$ & 5 & 5 & 5 & 4 & 5 & 4,8 & 0,3 & $\begin{array}{c}1,4 \\
4\end{array}$ \\
\hline & $\begin{array}{l}\text { Simplic } \\
\text { ity }\end{array}$ & 4 & 3 & 4 & 4 & 3 & 3,6 & 0.2 & 0,9 \\
\hline
\end{tabular}

Tabel 9. Pengujian Kualitas Faktor Reliability

$$
\begin{aligned}
\text { Reliability }= & \mathrm{w} 1 \mathrm{n} 1^{\prime}+\mathrm{w} 2 \mathrm{n} 2{ }^{\prime}+\mathrm{w} 3 \mathrm{n} 3 \ldots . . \\
= & 1,2+0,85+1,44+0,9 \\
& 4,39 * 20 / 100 * 100 \% \\
= & 87,8 \% \text { (Sangat Baik) }
\end{aligned}
$$

\begin{tabular}{|c|c|c|c|c|c|c|c|c|}
\hline \multirow[t]{2}{*}{ Faktor } & \multirow[t]{2}{*}{ Kriteria } & \multicolumn{4}{|c|}{$\begin{array}{l}\text { Tanggapan } \\
\text { Responden }\end{array}$} & & \multirow[t]{2}{*}{$\begin{array}{l}\text { Bob } \\
\text { ot }\end{array}$} & \multirow[t]{2}{*}{$\begin{array}{l}\text { Nil } \\
\text { ai }\end{array}$} \\
\hline & & 12 & 3 & 4 & 5 & & & \\
\hline \multirow[t]{2}{*}{$\begin{array}{l}\text { Usabil } \\
\text { ity }\end{array}$} & $\begin{array}{l}\text { Operabi } \\
\text { lity }\end{array}$ & 45 & 4 & 4 & 4 & $\begin{array}{l}4, \\
2\end{array}$ & 0,6 & $\begin{array}{l}2,6 \\
4\end{array}$ \\
\hline & Training & 43 & 3 & 5 & 4 & $\begin{array}{l}3, \\
8\end{array}$ & 0,4 & $\begin{array}{l}1,5 \\
2\end{array}$ \\
\hline
\end{tabular}

Tabel 10. Pengujian Kualitas Faktor Maintability

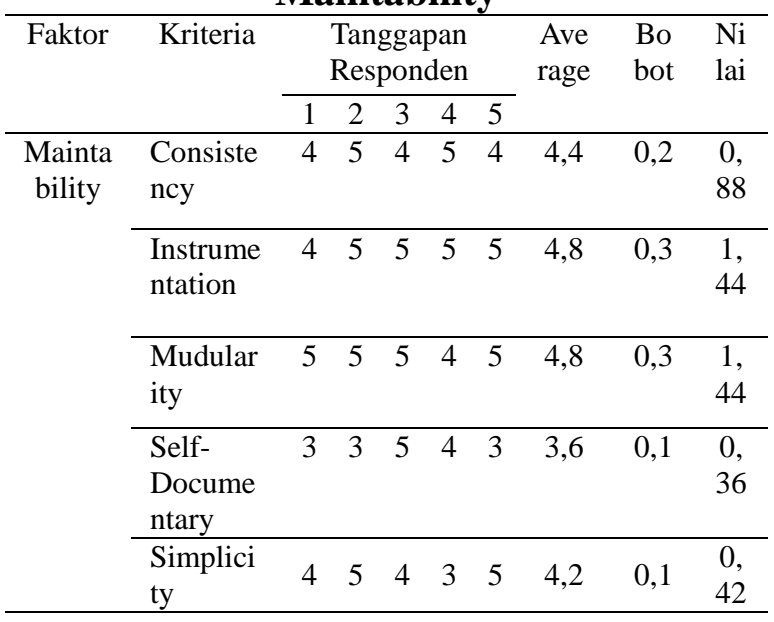

$$
\begin{aligned}
\text { Maintability }= & \mathrm{w} 1 \mathrm{n} 1{ }^{\prime}+\mathrm{w} 2 \mathrm{n} 22^{\prime}+\mathrm{w} 3 \mathrm{n} 3 \\
= & 0,88+1,44+1,44+0,36+0,42 \\
& 4,54 * 20 / 100 * 100 \% \\
= & 90,8 \% \text { (Sangat Baik) }
\end{aligned}
$$

Tabel 11. Pengujian Kualitas Faktor Usability 


$$
\begin{aligned}
\text { Usability } & =\mathrm{w} 1 \mathrm{n} 1^{\prime}+\mathrm{w} 2 \mathrm{n} 2 \\
& =2,64+1,52 \\
& =4,16 * 20 / 100 * 100 \% \\
& =83,2 \% \text { (Baik) }
\end{aligned}
$$

Nilai $=$ efficiency ' + reliability ' + Usability '+Maintsbility

$$
\begin{aligned}
& =(4,46+4,39+4,54+4,16): 4 \\
& =4,3875 \\
& =4,3875 * 20 / 100 * 100 \\
& =87,75
\end{aligned}
$$

Berdasarkan hasil pengujian kualitas perangkat lunak menggunakan McCall's dalam penelitian ini dibuktikan bahwa kualitas perangkat lunak aplikasi KMS yang dihasilkan dengan empat kriteria aspek McCall's yaitu aspek Reliability, Maintainability, Efficiency, Usability, maka dapat disimpulkan bahwa hasil pengujian di atas dapat disimpulkan bahwa tingkat kualitas prototype aplikasi KMS, dengan persentase $87,75 \%$ sangat baik.

Dari beberapa pengujian yang dilakukan maka hasil yang didapatkan dapat dilihat pada tabel berikut:

\section{Tabel 12. Hasil Teknik Pengujian}

\begin{tabular}{cccc}
\hline No & $\begin{array}{c}\text { Teknik } \\
\text { Pengujian }\end{array}$ & Keberhasilan & Kriteria \\
\hline 1 & $\begin{array}{c}\text { Forum } \\
\text { Group } \\
\text { Disscusion } \\
\text { (FGD) }\end{array}$ & $90 \%$ & Diterima \\
\hline 2 & Mc'Calls & $87,75 \%$ & $\begin{array}{c}\text { Sangat } \\
\text { Baik }\end{array}$ \\
\hline
\end{tabular}

Berdasarkan hasil pengujian, pengujian untuk hipotesis kedua dalam penelitian ini dibuktikan bahwa kualitas KMS pada Akademi Pariwisata Nusantara yang dihasilkan jika diukur berdasarkan kualitas perangkat lunak Mc'Calls mancapai harapan semula yaitu Sangat Baik hasil presentase dari Responden adalah 87,75.

\section{SIMPULAN}

\section{A. Simpulan}

Berdasarkan uraian-uraian dari babbab diatas, maka dapat disimpulkan beberapa simpulan, yaitu:

1. KMS berbasis web ini telah diuji kebutuhan fungsionalnya dengan menggunakan Forum Group Disscusion menghasilkan tinggat keberhasilan $90 \%$ dan dapat menyimpan pengetahuan dan pengalaman karyawan dengan baik.

2. Hasil pengujian keberhasilan KMS berbasis web yang diterapkan tersebut terhadap karyawan Akademi Pariwisata Nusantaradengan metode McCall's mencapai $87,75 \%$ dengan kriteria sangat baik.

\section{DAFTAR PUSTAKA}

[1] Becerra-Fernandez, I., Rajiv Sabherwal. 2010, Knowledge Management : system and processes, United States of America.

[2] Dunamis., 2013, Successful Implementation of $K M, \quad \mathrm{~J} . \quad$ Budi Soesetyo, PT Dunamis Intra Sarana, Jakarta, Indonesia.

[3] Frost, A, 2013, 'Difining Knowledge, Information, Data', http://www.knowledge-managementtools.net. viewed 12 Oktober 2016, http://www.knowledge-managementtools.net/knowledge-informationdata.html.

[4] Hartono, Bambang, 2013, Sistem Informasi Manajemen Berbasis Komputer, Rineka Cipta, Jakarta.

[5] Prihartono, A. 2013, 'Prototipe Knowledge Management Sistem Informasi Akademik Pada Akademi Sekretari Budi Luhur', Tesis, M.Kom, Universitas Budi Luhur, Jakarta.

[6] Vercellis, Carlo. 2009, Business Intelligence: Data Mining and Optimization for Decision Making, John Wiley \& Sons Ltd,. United Kingdom . 